\title{
Healing Is Believing: Yeon Gaesomun and Xue Rengui in the Making of Mid-Seventh-Century Tang-Goguryeo War Narratives
}

\author{
YI Seokgu \\ National Taiwan Normal University, Taipei, Taiwan
}

\begin{abstract}
This paper examines how historical narratives and fictional narratives treat China's loss in Tang-Goguryeo War differently to heal China’s damaged pride. Emperor Tang Taizong (599-649) invaded Goguryeo in 645 but failed to conquer her because of severe weather and strong resistance led by Yeon Gaesomun (603-666). This paper argues that official histories including Jiu Tangshu (Old Book of Tang) and Xin Tangshu (New Book of Tang) focus on Emperor Tang Taizhong's legitimacy to invade Goguryeo because Yeon Gaesomun's coup d'etat overthrew Yeongnyu-wang. These two histories also pay extra attention to Yeon Gaesomun's negative characters. Novels about Tang-Goguryeo War including Xue Rengui zheng Liao shi lue (薛仁贵征辽事略), Tang shu zhi zhuan tong su yan yi (唐书志传通俗演义), and Shuo Tang hou zhuan (说唐後传) take a different approach to heal China’s wounded pride. Instead of focusing on diplomatic and military legitimacy, these stories blur China's loss by creating a national hero Xue Rengui whose military skills, loyalty to Tang Dynasty, and dauntless rescue of Emperor Tang Taizong were constantly emphasized.
\end{abstract}

Keywords: Tang-Goguryeo War, Yeon Gaesomun, Xue Rengui, historical narratives, fictional narratives

\section{Introduction}

Traditionally, China had built a self-centered view of the world and wanted to exercise influence neighboring countries and races through it. In cultural and academic fields, neighboring countries' resistance was not so strong, even had been receptive to it. So-called “Sino-centrism 中华思想 or 华夷思想” is based on cultural advantage and pride. ${ }^{1}$ Sino-centrism influenced on political field, too. Contrary to aspects in cultural and academic fields, however, the political influence was unwelcome for neighboring countries and races because it can be a menace to their political independence. It had given rise to complications between China and others. “Goguryeo-Tang war 高唐之戰” (hereafter Go-Tang war) is a typical conflict between Sino-centrism and anti-Sino-centrism. It is not only a struggle for hegemony but also a conflict between two views of the world. However, the result was different from Tang dynasty's hope and they needed to treat the aftermath. How to remember the event, especially their enemy shows the way they treated the trauma. At that time, Yeon Gaesomun (渊盖苏文) as a Goguryeo’s political and military leader struggled against Tang dynasty.

\footnotetext{
YI Seokgu, Ph.D. Candidate, Department of Chinese, College of Liberal Arts, National Taiwan Normal University.

1 The word “Huayi (华夷)” shows the recognition that distinguishes “Hua (华)” and “Yi (夷)”. For China, “Hua (华)” means “oneself”, “civilized” and “Yi (夷)” means “others”, “uncivilized”.
} 
Through Chinese historical narrative and fictional narrative about Yeon Gaesomun and Go-Tang war, we can find Chinese how to heal the trauma caused by Go-Tang war.

\section{Go-Tang War in Historical Narrative}

\section{Did Go-Tang War Cause Tang's Trauma?}

We start discussion on a premise that Tang's trauma caused by Go-Tang war. However, we need to examine the validity of the premise. According to historical records, the premise is skeptical. During the reign of Emperor Taizong (太宗), Tang tried to conquer Goguryeo three times, annexed a part of fortresses located on Liaodong (辽东) and damaged to Goguryeo seriously. The first conquest is recorded in Jiu tang shu Taizong-Benji (旧唐书太宗本纪):

Gui hai (癸亥) day 4th month (19th year一贞观19年, A.D. 645), the commander of Liaodong conquest, Duke Ying guo (英国公) Li Ji (李绩) attacked Gaimou fortress (蓋牟城) and took it.

Jia shen (甲申) day 5th month Emperor (Taizong) led armored cavalry, joined Li ji’s troop and sieged Liaodong fortress (辽东城). Because hot wind blew at that time, (Tang army) shot burning arrows, so that all of roof and tower in the fortress were burnt out. Finally Liao dong fortress was taken.

Bing chen (丙辰) day 6th month (Tang) army arrive in Anshi fortress (安市城).

Ding si (丁巳) day Goguryeo’s troop of 150,000 came to defend Anshi fortress from imperial army, which was led by Go Yeonsu (高延寿) and Go Hyaejin (高惠真) who were generals of Goguryeo. Li Shiji (李世绩) (Li Ji)’s troop attacked them. Imperial troop lured them from high hill and confronted them, so that Goguryeo's army fell into confusion and lots of Goguryeo soldiers were killed. Uncountable Gogouryeo soldiers were killed and captured. A lot of them, including Go Yeonsu, surrendered. Cause of this, the mountain was changed the name from Xing shan (幸山) to Zhu bi shan (驻跸山) (it means "a mountain where emperor stay on the way”). A monument which recorded the achievement was raised and Emperor Taizong held a banquet of two days.

Autumn 7th month Li Shiji's troop moved to Anshi fortress attacked it. It was not taken until 9th month, so Tang troops were withdrawn. ${ }^{2}$

According to the records, Tang won overwhelming victory before withdrawal from Anshi fortress. Although Tang army withdrew from An shi fortress, Tang army’s damage is not serious. According to Xin tang shu Dong yi-Lie zhuan (新唐书东夷列传): “When the conquest was started, there are 100,000 soldiers and 10,000 horses. When they returned, deaths are only over a thousand, eight tenth of horses were dead and hundreds sailors were dead in 70,000". ${ }^{3}$ It is hard to assume that slight damage causes Tang's trauma.

Nevertheless, it cannot conclude that the Go-Tang war was not the cause of Tang's trauma, because there are some records and comments which are different with the records about Tang's victory. For instance,

\footnotetext{
2 “癸亥, 辽东道行軍大总管、英国公李绩攻盖牟城，破之。‥甲申，上亲率铁骑与李绩会围辽东城，因烈风发火驽，斯 须城上屋及楼皆尽, 麾战士令登, 乃拔之。

六月丙辰, 師至安市城。丁已, 高丽别将高延壽、高惠真帅兵十五万来援安市，以拒王師。李绩率兵奋击，上自高峰引 军临之, 高丽大溃, 杀获不可胜纪。延壽等以其众降，因名所幸山为驻跸山，刻石纪功焉。赐天下大酺二日。

秋七月, 李绩进军攻安市城, 至九月不克, 乃班师”, Jiu tang shu Taizong-Ben ji(旧唐书太宗本纪) (translated by the present writer).

3 “始行, 士十万, 馬萬匹; 逮还, 物故裁千余, 马死十八。船師七万, 物故亦数百”, Xin tang shu Dong yi-Lie zhuan (新唐 书东夷列传) (translated by the present writer)
} 
Taizong regretted launching the conquest and said: “If Wei Zheng (魏徵) were still alive, he would never have let me launch this campaign”. ${ }^{4}$ Taizong's will and historian’s comments also show other recognition about Liaodong conquest. ${ }^{5}$ Through Liaodong campaign, Tang wanted to strengthen influence in neighboring countries $^{6}$, revenge for Sui's (隋) and overcome mental handicap of Goguryeo ${ }^{7}$. The record about Yeon Gaesomun in Ben-ji (本纪) intimated the purpose of Tang's Liaodong Campaign. ${ }^{8}$ It is that Yeon Gaesomun murdered King Yeongnyu (荣留王). According to these factors, “to discipline Yeon Gaesomun” was a symbolic reason of Launching Liaodong campaign. For these reason, although Tang army made marked achievements through Liaodong campaign, yet it was certain that Tang failed to achieve initial aim. Therefore, I suppose that the failure of Go-Tang war might be origin of Tang's trauma.

\section{How Did Historical Narrative Treat the Trauma Caused by Go-Tang War?}

Although we make sure the failure of Liaodong campaign caused Tang's trauma, it is hard to say that historian recorded intentionally Go-Tang War to treat the trauma since it could mean distortion of history. Whether intentional or not, history in itself is not the product of ideal object. ${ }^{9}$ Through textualization by historian, particular facts can be understood on causal relationship and have a historical meaning. It means, conversely speaking, that historian arranges and composes particular fact by his interpretation and ideology. Historical record and its narrative attitude present its recognition and treatment about aftereffects of Go-Tang War.

\footnotetext{
4 "In Liaodong campaign, Goguryeo and Mohe attacked, Li Ji and others fought and defeated them. In returning, (Taizong) said sorrowfully: 'If Wei Zheng were still alive, he would never have let me launch this campaign' (辽东之役, 高丽、靺鞨犯阵, 李 绩等力战破之。军还, 怅然曰: 「魏徵若在, 吾有此行邪。」)”, Xin tang shu Wei zheng-Lie zhuan 新唐書魏徵列传 (translated by the present writer).

5 "4th month Summer 8th year (King Bojang 8th year, A.D. 649), Tang Taizong demised and left to abandon Liaodong campaign in his will.(八年，夏四月，唐太宗崩，遗照罢辽东之役)”, Samguk-Sagi Goguryeo-Bongi Bojang-Wang Ha (三国史記高句丽 本纪宝藏王下) (translated by the present writer).

"If Wen Huang (Emperor Taizong) was steadily cultivated an heir in personal, his will had not focused on Goguryeo. If his personnel management was like in the early his era, acceptance of expostulation had been equal to the days when Wei Zheng was alive. (若文皇自定储於哲嗣, 不骋志於高丽; 用人如贞观之初, 纳谏比魏徵之日。)”, Jiu tang shu Taizong-Ben ji 旧唐書太 宗本纪 (translated by the present writer).

${ }^{6}$ Before launching Liaodong campaign, conflict between Goguryeo and Tang often occurred. Tang intervened territory dispute between Goguryeo and Silla and Goguryeo's block tribute on Tang. For the details, refer to Jiu tang shu Taizong-Ben ji, Jiu tang shu Dong yi-Lie zhuan, Xin tang shu Taizong-Ben ji, Xin tang shu Dong yi-Lie zhuan, Samguk-Sagi Goguryeo Bongi etc.

${ }^{7}$ When Taizong's troop crossed Liaoze (辽泽), Taizong ordered to bury Sui soldiers corpse. It means Taizong was conscious of the campaign of Sui dynasty. Refer to Jiu tang shu Dongyi-Lie zhuan, Xin tang shu Taizong-Ben ji.

${ }^{8}$ There is a the following record in Jiu tang shu Taizong-Ben ji:

“In this year(16th year一贞观 16 年, A.D. 642), the minister of Goguryeo Gaesomun murdered his lord Go Mu (高武) (King Yeongnyu) and enthroned Jang 藏 (King Bojang 宝藏), who was a son of Go Mu’s elder brother.(是歲，高丽大臣盖苏文斌其 君高武，而立武兄子藏为王)”。

In Ben-ji which is centered Emperor, this event was recorded. It means this event has historical meaning on Taizong and his era. At that time, King Yeongnyu had been promoting a policy to recover the relationship with China after Goguryeo-Sui war. Yeon Gaesomun was the leader of hardliners about policy toward Tang. These might mean a serious menace for Tang. In this point of view, Yeon Gaesomun was one of the important occasions of launching Liaodong Campaign.

${ }^{9}$ See Hayden (1983), p. 426.

"I have maintained that the style of a given historiographer can be characterized in terms of the linguistic protocol he used to prefigure the historical field prior to bringing to bear upon it the various 'explanatory' strategies he used to fashion a 'story' out of the 'chronicle' of events contained in the historical record. These linguistic protocols, I have maintained, can be further characterized in terms of the four principal modes of poetic discourse. Using the tropes of Metaphor, Metonymy, Synecdoche, and Irony as the basic types of linguistic prefiguration, I have discussed the modes of consciousness in which historians can implicitly or explicitly justify commitment, and ideological implication respectively”.
} 
"Glorification" is a way that historical narrative treats Tang’s trauma caused by Go-Tang War. As we examined, Tang's victory was remarkable in historical record about Go-Tang War. On contrary, the record about Tang's damage or Goguryeo's achievement was relatively short. ${ }^{10}$ It presents that historical narrative how to treat the trauma. By bringing out Tang's merit and evading Tang's damage, memories about the war are glorified. Although it was not on purpose, glorious memories about the war remained through focusing and evading. Consequently, historical narrative produced the effect which removed or disregarded dark side of the war.

"Justification" is another way to treat the trauma. Historical narrative justified Liaodong campaign by bringing out cause that was mainly the enemy's improperness. It was Yeon Gaesomun that recorded as improper enemy. He was actual power and leader of hardliners in Goguryeo therefore it is no wonder that Yeon Gaesomun was recorded as the symbol of enemy in historical narrative. Actually, the records about Yeon Gaesomun are mostly negative. For instance:

In this year, the minister of Goguryeo Gaesomun murdered his lord Go Mu and enthroned Jang (藏), who was a son of Go Mu's elder brother. ${ }^{11}$

There was a man named Gaesomun or Gaegun, whose surname was Cheon. He himself said he was born from water to seduce people and he was cruel. His father was Dongbu-Daeyin (东部大人) Daedaero (大對庐) (the Prime minister of Goguryeo). After his father was dead, he was supposed to succeed his father's office, but he could not do since people hate him. He apologized to the people giving a deep bow and said "Please let me succeed the office. If I am not proper to take the office, I will not have anything to regret”. People sympathized with him, so he could succeed the office. Because he was cruel and immoral, all minister and Gunmu (King Yeongnyu) conspired to kill him. Gaesomun sensed it, summoned them all under the pretext of inspection of troops. After served with meals and invited ministers come to see, he immediately killed them all when they arrived at there. Above one hundred were killed at there. (Yeon Gaesomun) was rush to king's palace, murdered Gunmu (King Yeongnyu) destroyed his body and abandoned it in a ditch.He enthroned Jang (King Bojang) as the King, who was son of Gunmu (King Yeongnyu)’s brother. He became Mangniji (莫离支)—that was like Bing bu-Shang shu (兵部尚书) (Defense minister) and Zhong shu ling (中书令) (Prime minister) of Tang一by himself and dominated (Goguryeo). His appearance was robust and handsome and his beard was wonderful. His crown and dress was trimmed with gold. He wore five swords and people did not dare look up at him. When he rode horse, made a noble man lie face down on the ground to step on it and rode it. When he entered and left military camp, passage was restricted. All passengers dodged with fear, someone ran into brooklet or sunken place. ${ }^{12}$

These records are emphasizing Yeon Gaesomun's negative aspects. It is a good reason for launching military campaign. Actually, Taizong expressed his plan in Xin tang shu Dong yi-Lie zhuan:

Thereupon, Emperor wanted to conquer it on personal, so invited old men in Chang’an (長安) and said: “Originally, Liaodong was Chinese territory. However, Mangniji murdered his lord, so I will go to punish him. I assure you that I should care for your sons following me. You don't need feel pity for them”. Emperor bestowed cloth and grain on them immediately. A crowd of retainers dissuaded from launching the campaign. Emperor said: "I already know this three are

\footnotetext{
${ }^{10}$ See footnotes 2 and 3 in this paper.

11 See footnote 8 in this paper.

12 “有盖苏文者, 或号盖金, 姓泉氏, 自云生水中以惑众。性忍暴。父為东部大人、大對庐, 死。盖蘇文当嗣, 國人惡 之, 不得立。顿首谢众, 请摄职, 有不可, 虽废无悔。众哀之, 遂嗣位。残凶不道, 诸大臣与建武议诛之, 盖苏文觉, 悉召诸部, 给云大阅兵, 列馔具请大臣临视, 宾至尽杀之, 凡百余人。驰入宫杀建武, 残其尸投诸沟。更立建武弟之子 藏为王, 自为莫离支, 专国, 犹唐兵部尚书、中书令职云。貌鬼秀, 美须髯, 冠服皆饰以金, 佩五刀, 左右莫敢仰视。 使贵人伏诸地，践以升马。出入陈兵，长呼禁切，行人畏窝，至投坑谷”, Xin tang shu Dong yi-Lie zhuan (新唐书东夷列传) (translated by the present writer).
} 
unpropitious: to leave center and get the edges, to throw high one and take low one, to abandon near place and go to the far place. It is Goguryeo conquest. However, Gaesomun murdered his lord and ministers of Goguryeo had been killed blindly. People of a kingdom are waiting for impatiently for help. Who try to dissuade me from the conquest doesn't understand this". ${ }^{13}$

Tang's purpose of the conquest is expressed in these records. Taizong definitely pointed out the reason of military campaign was Yeon Gaesomun's atrocity. Whatever the result may be, it justified the military campaign in itself. In this frame, the conquest has a meaning as a military campaign to chastise vice and to recover justice. It makes the military campaign free from the result and Tang's military campaign can be justified by its motive. Righteous motive treats the trauma by offsetting unsatisfied result. Historical narrative cannot change particular fact, but how to arrange each fact and how to recognize particular fact in a context can change the meaning of the particular fact. Historical narrative tried to treat the trauma with this way.

\section{Go-Tang War in Fictional Narrative}

\section{Fictional Frame of Go-Tang War}

Historical events are popular material for a narrative literature. Especially, big event such as war is very fascinating material. Go-Tang war also has been used frequently as one of the good material. For instance, fictions such as Xue Rengui Zheng dong Shi lue (薛仁贵征东事略), Xue Rengui Zheng dong (薛仁贵征东) etc. and dramas such as Xue Rengui Jin yi huan xiang (薛仁贵衣锦还乡), Mo li zhi Fei dao dui jian (摩利支飞刀 对箭), Xue Rengui Kua hai Zheng dong Bai pao ji (薛仁贵跨海征东白袍记) are the works based on Go-Tang War. ${ }^{14}$ It is interesting that Xue Rengui emerged as main character in these narratives. As we confirmed, Xue Rengui was not impressive in historical narrative. Although his achievement of Go-Tang War was recorded in his Lie zhuan (列传), yet it was not as much as change result of the war. ${ }^{15}$ He distinguished himself in Anshi fortress battle, but it was just a starting of his promotion. ${ }^{16}$ According to historical records, there was no

\footnotetext{
13 “於是帝欲自将讨之, 召长安耆老勞曰: ‘辽东故中國地, 而莫离支贼杀其主, 朕将自行经略之, 故与父老约: 子若孙从 我行者, 我能拊循之, 冊庸恤也’。即厚赐布粟。群臣皆劝帝冊行, 帝曰: ‘吾知之矣, 去本而就末, 舍高以取下, 释近而 之远, 三者为不祥, 伐高丽是也。然盖苏文斌君, 又戮大臣以逞, 一國之人延颈待救, 议者顾未亮耳, ”, Xin tang shu Dong yi-Lie zhuan (新唐书东夷列传) (translated by the present writer).

14 See Shin Kyeong Seub (2007), pp. 225-247.

15 Jiu tang shu Xue Rengui-Lie zhuan (舊唐书薛仁贵列传), Xin tang shu Xue Rengui-Lie zhuan (新唐书薛仁贵列传).

16 “Xue Rengui was a native of Longmen in Jiangzhou. In the late Zhenguan (Taizong age), Taizong launched to conquer Liaodong. (At that time), Rengui received General Zhang Shigui in audience and applied for serving in General Zhang Shigu’s camp. When he arrived at Andi (Anshi fortress), You Langjiang (military officer) Liu Angwei was surrounded by enemies in danger. Rengui go to rescue him. He cut off the enemy general's head with gallping his horse. He hung it on his saddle. All of enemies bent themselves with feeling fear. Rengui became famous for this. When Tang's large army sieged Anshi fortress, Goguryeo Mangniji sent an army 250,000 strong led by General Go Yeonsu and Go Hyejin to keep. They took up position in a mountain. Taizong ordered to each General to attack on all sides. Rengui wanted to distinguish himself with his combat ability, so he wore white battle armor, had a pike and wore a big bow at his side. At the head, he rushed to enemies with shouting, the enemies ran away separately. Tang's troops take the chance, enemies gave away. Taizong had been viewing and asked that the vanguard was who. Taizong specially call him and bestowed two horses, forty rolls of silk and favored him with Youji general and Yunquanfu Guoyiand bestowed ten prisoners. (薛仁贵，㖓州龙门人。贞观末，太宗亲征辽东，仁贵谒将军张士贵应募， 请从行。至安地, 有郎将刘君昂为贼所围甚急, 仁贵往救之, 跃马径前, 手斩贼将, 悬其头于马鞍, 贼皆慑伏, 仁贵遂 知名。及大军攻安地城, 高丽莫离支遣將高延寿、高惠真率兵二十五万来拒戰, 依山结营, 太宗分命诸将四面击之。仁 贵自恃骁勇, 欲立奇功, 乃异其服色, 著白衣, 握戟, 腰鞬张弓, 大呼先入, 所向无前, 贼尽披靡却走。大军乘之, 赋 乃大溃。太宗遥望见之, 遣驰问先锋白衣者为谁, 特引见, 赐马两匹、绢四十匹, 擢授游击将军、云泉府果毅, 仍令北 门长上, 并赐生口十人)”, Jiu tang shu Xue Rengui-Lie zhuan (舊唐书薛仁贵列传) (translated by the present writer).
} 
engagement between Xue Rengui and Yeon Gaesomun. Nevertheless, fictional narratives about Go-Tang War adopted the frame which was the match between Yeon Gaesomun and Xue Rengui. Although it is a distortion in history, however it is no wonder in fiction. The points are why symbols of the match are Xue Rengui and Yeon Gaesomun and whether it could be a treatment for the trauma or not.

\section{Class and Treatment for the Trauma}

Although the memories of Go-Tang War were shocked as making trauma, yet it might fade away as time goes by. Nevertheless, it is not the memories of war disappeared clearly. It changes intoicon or symbol and exists in a culture. Xue Rengui and Yeon Gaesomun exist as symbol in fiction. In historical narrative, Yeon Gaesomun was a factor of Tang's military campaign. In fictional narrative, however, Yeon Gaesomun was not only factor of the war but also menacing enemy. The menace is military arts, which is expressed as "flying sword". ${ }^{17}$ The enemy's military arts embodied the fear of enemy. Xue Rengui is the hero who defeated enemy. Through hero's victory in fiction, vague fear and trauma caused by enemy could become lighter or disappeared mentally. In this point, Xue Rengui was the most suitable. He was a hero in a success story which rose to fame from obscurity and had good military arts. In addition, According to historical records Xue Rengui participated in the campaign as a private soldier. ${ }^{18}$ These might be factors which general public can feel empathy. Through Xue Rengui, people not only treat the trauma of the war but also have a pride as a commoner who is able to do something that even high class failed.

\section{Conclusion}

War is an intense event whether winner or loser. Mid-Seventh-Century Go-Tang War was a chance which was able to maintain prosperity of empire by strengthening influence about neighboring countries. Although failure of Go-Tang War did not cause fall of the empire, yet it became a trauma. Trauma is caused by intense experience such as war, therefore "how to remember the experience" is the important point to treat trauma. Two kinds of narratives show different ways to recognize Go-Tang war. Historical narrative recognized the war

\footnotetext{
17 In Xue Rengui Zheng Liao shi lue (薛仁贵征辽事略), Yeon Gaesomun exhibited his military arts on the first engagement between Tang army and Goguryeo army: “(Taizong) appointed Duke Yingguo Li Shiji general, Jingde was the vanguard. Attacked Dengzhou Penglaige and crossed Heifeng kou on the sea, the troops arrived at eastern seaside, about 30,000 enemies came to meet. There is a general stood uphead of the camp, who wore Sanchazijin crown, wore Jiangshifu, held a big sword rode Chiqiu horse, wore two bows at his side and slung five flying swords over his back. He said: "I am Mangniji Galsomun”. Taizong said: "If anyone gets the enemy's head, I will raise him to the feudal lord of 10,000". A general fought with him a few times, Mangniji hit Jingde, he dodged and held Gaesomun's sword with left hand and didn't release Qingfeng sword, raised a whip made with bamboo. At that time, Mangniji drew flying sword on his back. Jingde came back to his camp. Mangniji drove troop to kill them. Taizong failed, Tang army got into a panic, parasol was turned and flag was crooked. “拜英国公李世绩为元帅, 敬德作先 锋, 起军三十万, 御驾亲征。打登州蓬莱阁过海黑风口, 军才达东岸, 迎头的兵来约及三万有余。阵前捧一员将, 顶三 叉紫金冠，披㖓狮服，横一柄大杆刀，跨赤虬马，左右带兵器两鞬弓，身背飞刀五口，阵前耀武自言: ‘吾乃莫离支葛苏 文也。’太宗传圣旨: ‘若擒取贼首者, 当封万户侯。”一將出馬交戰数合, 莫离支刀䢃敬德, 敬德闪过, 左手拿住刀杆狻 猊爪, 不放青锋刀, 腕上颩颩竹节鞭, 举起鞭来, 莫离支背上取出飛刀在手, 敬德拨马归阵。莫离支催兵掩杀, 太宗失 败, 兵荒将乱, 伞倒旗斜。)”, Xue Rengui Zheng dong Shi lue (薛仁贵征辽事略) p. 13, (translated by the present writer).

${ }^{18}$ Xue Rengui was born in Jiangzhou Long men. From his childhood, he was raised in poverty and lived off the land. When he would hold his parents' funeral, His wife said "you have an excellent ability. If your time is coming, it must become famous in the world. Now, Emperor should conquer Liao dong, so he want brave fighter. This is a rare opportunity. Why don't you try to distinguish yourself in this conquer? It is not late to hold funeral after you get wealth and rank.” So, Rengui immediately went to General Zhang Shigui and applied for military conscription. (薛仁贵, 绛州龙门人。少贫贱, 以田为业。将改葬其先, 妻柳 曰：“夫有高世之材, 要须遇时乃发。今天子自征辽东, 求猛将, 此难得之时, 君盍图功名以自显? 富贵还乡, 葬未 晚。”仁贵乃往见将军张士贵应募。), Xin Tangshu Vol. 124.
} 
based on "glorification" and "justification", therefore tried to the war's result which was fatal factor. On the other hand, fictional narrative based on common people's recognition was different with historical narrative. They were free from result of the war relatively since the war was not their choice. However, they were still not free from the war in ethnic boundary whether they had been living in the age or not. Fictional narrative focused on a hero, Xue Rengui who was commoner by birth. His success and achievement were not only hope but also pride of populace who protect their ethnic. The trauma is caused by an event and treated with the same way to recognize the event. According to the point of view, it is different how to recognize it. Class is one of the factors which decide the point of view. Two narratives about Go-Tang war show different ways to treat the trauma.

\section{References}

Jang Suyeon, Min Guandong (2011). A study of Xue ren gui zhuan’s origin. Seoul: 中国小说论丛 (Chinese Fiction Study), 34, 73-97.

Hayden, W. (1983). Metahistory: The historical imagination in nineteenth-century Europe. Baltimore: Johns Hopkins Press.

Kim, B. 三國史記 (History of the Three Kingdoms).

LIU, X. 旧唐书 (Jiu Tangshu, Old book of Tang).

LU, X. (2009).中国小说史略 (A brief history of Chinese fiction). Taipei: 五南.

LUO, G. Z. (1987). 說唐演義 (一，二) (Heroes of Tang Dynasty I , II ). Taipei: 风云时代.

OUYANG, X. 新塘書 (Xin Tangshu, New book of Tang).

Plaks, A. H. (Ed.). (1977). Chinese narrative-Critical and theoretical essays. New Jersey: Princeton University Press.

Seo, G. H. (2004). 中国小说史 (History of Chinese fiction). Seoul: Seoul National University Press.

Shin, K. S. (2007). A Study of Yeon-Gaesomun. Figures: Focus on the Origin and Transition of Yeon-Gaesomun's Stories in China. The Review of Korean and Asian Political Thoughts, VII(1), 225-247.

Twitchett, D. (1992). The writing of official history under the T'ang. New York: Cambridge University Press.

宋元平話五種 (Five Kinds of Romance in Song-Yuan Dynasty). (1981). Taipei: 河洛图书. 